\title{
研究
}

\section{等方性ストロンチウムフェライト磁石に およぼす塩素の影響*}

\section{伊藤 俊治 ${ }^{* *}$, 梶永 剛㤵 ${ }^{*}$, 今井 郁子**, 遠藤 一哉**}

Shunji Ito, Yoshihiro Kajinaga, Ikuko Imai, Ichiya Endo: Effect of chloride on the magnetic properties of isotropic strontium ferrite.

The effects of chloric ion on the magnetic properties of isotropic strontium ferrite were studied. The hematite obtained from waste pickle liquor was used. It contained $0.1 \sim 0.3 \mathrm{wt} \%$ chloric ion as chloride.

Chloric ion in the hematite was reduced to one half of the initial amount by washing with water. Though the green density remained unchanged after dechlorination, it was found that sintered density of ferrite obtained from the dechlorinated hematite was $5 \sim 10 \%$ higher than that of as received. Remanence and maximum energy product of the ferrite produced from the dechlorinated hematite were $10 \sim 15 \%$ higher and intrinsic coercive force was about $10 \%$ lower than those from non-dechlorinated ferrite.

In the case of the ferrites obtained from hematite contatining $0.2 \sim 5.0 \mathrm{wt} \%$ chloric ion as added in the form of ferrous chloride, magnetic properties of those having molar ratio of both $2 \mathrm{Fe} / \mathrm{Sr}=6.00$ and $2 \mathrm{Cl} / \mathrm{Sr}$ $=1.00$ were improved $15 \sim 20 \%$ over those from not compensated ferrites. The maximum values of the magnetic properties were obtained in the range of $0.8 \sim 1.0 \mathrm{wt} \%$ chloric ion.

The chloric ion was found to exist as strontium chloride by X-ray diffraction. It was considered that the effects of chloric ion on the magnetic properties are due to the improved densification caused by liquid phase sintering of strontium chloride.

(Received January 5, 1974)

\section{I 緒 言}

ストロンチウムフェライト磁石の $80 \mathrm{wt} \%$ 以上を占め る酸化第二鉄（以下，へマタイトという）は，従来熱間 王延鋼板の酸洗によって生成する廃酸中の硫酸第一鉄を 7 水塩または 1 水塩の形態で晶析分離し，これらを高温 で焙烇し，ヘマタイトに分解したむのを用いてきた1)。 近年，酸洗液として临酸が用いられるようになり，発生 する塩酸廃酸は高温の下で直接, 喷蓩焙焼され処理され る2)ようになった，廃酸中の塩化第一鉄はつぎの反応3)

$$
2 \mathrm{FeCl}_{2}+2 \mathrm{H}_{2} \mathrm{O}+\frac{1}{2} \mathrm{O}_{2}=\mathrm{Fe}_{2} \mathrm{O}_{3}+4 \mathrm{HCl}
$$

によりへマタイトとして得られる，てのへマタイトは副 生へマタイトと呼ばれ，フェライト磁不用原料に多く用 いられている4,5).

この焙焼反応は $500^{\circ} \mathrm{C}$ 以上の高温で行われるが，乙 のヘマタイトには通常塩素が化合物の形（以下，塭菜と いう）で含有されており，塩素分として $0.05 〜 0.3 \mathrm{wt} \%$
含まれる。このへマタイトをフェライト磁石の原料に用 いる場合，塩素の存在は磁気特性〔とこでは残留磁束密 度 $B_{r}$, 抗磁力 ${ }_{I} H_{c}$, 最大エネルギー皘 $(B \cdot H) \max$ に悪

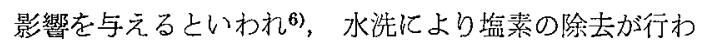
れている，本報では副生へマタイトに含まれる微量の倎 菜が等方性ストロンチウムフェライト磁石（以下，フェ ライトという）の磁気特性に与える影響につき，フェラ イトを実験室的に製造し検討した.

残留磁束密度の大きなフェライトを得るためには，高 密㡲になるよう焼成するか，または磁場成形などの方法 により異方性磁石とする方法が採られている，高密度を 得るには，死粉密度を高め，1200 $1400^{\circ} \mathrm{C}$ の高温度で 本焼成を行えばよいが，高温度，長時間の焼成ではフェ ライト結晶粒子が粗大化し抗磁力が低下し，著しい場合 に残留磁束密度它低下する. 乙の久点を防止する方法

* 昭和48年10月本協会秋季 (金沢) 飞て一部発表, 昭和49年 1 月 5 日受理

** 川崎製鉄(株)技術研究所, 千葉市川崎町 1 番地（テ280） 
として，フェライト粒子生成過程を利用する方法》， $\mathrm{Al}_{2} \mathrm{O}_{3}, \mathrm{Bi}_{2} \mathrm{O}_{3}, \mathrm{SiO}_{2}, \mathrm{TiO}_{2}, \mathrm{WO}_{2}$ などの金属酸化物を 微量添加する方法 $8,9,10)$, 酸化物以外の $\mathrm{CaF}_{2}, \mathrm{SrSO}_{4}$, $\mathrm{CaSO}_{4}$ などを微量添加する方法11,12,13)などがある。

本報ではフェライトの磁気特性向上のひとつの方法と して，もとあと副生へマタイトに含まれる塩素を微量添 加化合物として利网する方法につき検討を行ったので報 告する.

\section{II 実 験 方 法}

\section{II -1 原料}

副生へマタイトは川鉄化学(株)千葉工場の廃酸処理装 䈯 $\mathrm{A}, \mathrm{B}$ 扰よびC 系から得られたあのを用いた，それぞ

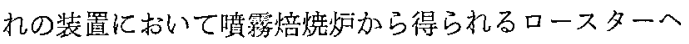
マタイト扰よ゙その次工程で得られるサイクロンへマタ イトの 2 種類について奏験を進めた。 てれらのへマタイ 卜は $0.5 \sim 1.5 \mu \mathrm{m}$ の微粒からなった凝集体であり，てれ らの平均径はロースターへマタイトで約 $8 \mu \mathrm{m}$, サイクロ ンヘマタイトで約 $6 \mu \mathrm{m}$ であった．とれらの化学組成お よび貲霧焙焼温度を Table 1 亿示す。なお，塭素を微 量添加化合物として利用する车験には Fig. 1 亿示す粒径 頻度分布をもつ $\mathrm{A}$ 系の焙焼炉炉底加ら直接得られた顆粒。 ロースターヘマタイトを用いた。

孷酸ストロンチウムは特級試薬を用いた。

II-2 脱湓素

磁気特性におよぼす塩薪の影響を調べるために，塩溸 を除く（以下，脱塩菜という）操作として，副生へマタ イトの水洗を行った. ヘマタイト $500 \mathrm{~g}$ に水 11 を加 え，よく摫拌したのち24時間放置後，上澄みを接て，

Table 1. Chemical analysis of spray-roasted hematite.

\begin{tabular}{r|c|c|c}
\hline Hematite & $\begin{array}{c}\mathrm{Fe}_{2} \mathrm{O}_{3} \\
(\text { wt } \%)\end{array}$ & $\begin{array}{c}\mathrm{Cl}- \\
(\text { wt } \%)\end{array}$ & $\begin{array}{c}\text { Spray-roasting } \\
\text { temperature }\left({ }^{\circ} \mathrm{C}\right)\end{array}$ \\
\hline *AC & 98.45 & 0.21 & \\
AC & 99.38 & 0.16 & 560 \\
$* \mathrm{AR}$ & 98.94 & 0.12 & \\
$\mathrm{AR}$ & 99.52 & 0.06 & \\
\hline$* \mathrm{BC}$ & 98.29 & 0.31 & \\
$\mathrm{BC}$ & 99.29 & 0.20 & 540 \\
$* \mathrm{BR}$ & 98.94 & 0.17 & \\
$\mathrm{BR}$ & 99.68 & 0.07 & \\
\hline$* \mathrm{CC}$ & 98.35 & 0.22 & \\
$\mathrm{CC}$ & 98.15 & 0.13 & \\
$* \mathrm{CR}$ & 98.94 & 0.19 & 6 \\
$\mathrm{CR}$ & 98.75 & 0.08 & \\
\hline
\end{tabular}

$A, B$ and $C:$ Names of treatment plants

$C$ : Cyclone hematite

$\mathrm{R}$ : Roaster hematite

* : not dechlorinated

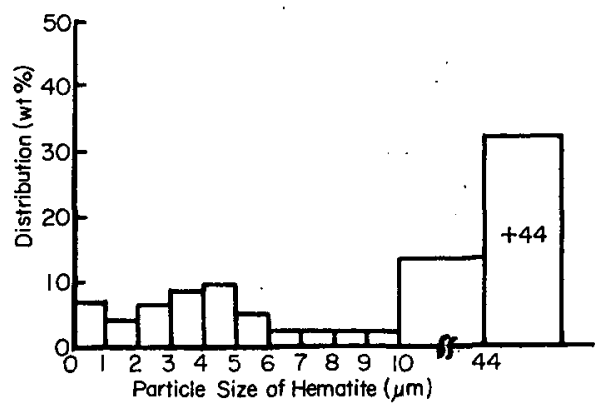

Fig. 1 Particle size distribution of hematite.

$100^{\circ} \mathrm{C} ， 24$ 時間乾燥したものを用いた。 Table 1 亿脱塭 素によるへマタイトの化学組成の变化を示す. 1 回の水 洗を行うことにより，40６0％脱塩菜されるととがわか る.

\section{II-3 原料の調製}

原料混合の過程で，へマタイトを $100^{\circ} \mathrm{C}, 24$ 時間空気 中で乾燥し，炭酸ストロンチウムとのモル比が $\mathrm{Fe}_{2} \mathrm{O}_{3}$ : $\mathrm{SrCO}_{3}$ で 6:1になるように秤量し，擂潰機にて30分間 乾式覧拌混合を行った。

塩素を微量添加化合物として利用する場合にはつぎの 手順によった，塩素を $0.12 \mathrm{wt} \%$ 含む A 系の顆粒状へマ タイトを粉砕，水洗などの前処理を行わず，そのままの 状態で武薬特級の炭酸ストロンチウムとのモル比が $6: 1$ になるよう科量し，乙れらを擂潰機にて10分間混合した (これらを以下，混合物という）.

ヘマタイトに対する塩素の重量割合は，混合物に試薬 特級の塩化第一鉄 $\left(\mathrm{FeCl}_{2} \cdot 3.8 \mathrm{H}_{2} \mathrm{O}\right)$ を所定量加え，へマ

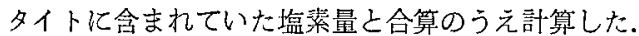

混合物 $(a \mathrm{~g})$ に塩化第一鉄を所定量 $(b \mathrm{~g})$ 扣え，後者の 鉄が全量酸化してへマタイトになるすのとし，モル比で つぎの式を満足するよう炭酸ストロンチウム $(c \mathrm{~g})$ を添 加する．乙扎を㬰験 I という。

$$
\begin{aligned}
& \mathrm{Fe}_{2} \mathrm{O}_{3}\left(\mathrm{FeCl}_{2} \cdot 3.8 \mathrm{H}_{2} \mathrm{O}\right. \text { 所定量 } \\
& \left.b \mathrm{~g} \text { 加生成する } \mathrm{Fe}_{2} \mathrm{O}_{3}\right) \text { のモル数 }=6.00 \\
& \mathrm{SrO}\left(\mathrm{SrCO}_{3}\right. \text { O㩐加量 } \\
& c \mathrm{~g} \text { からできる } \mathrm{SrO}) \text { のモル数 }
\end{aligned}
$$

つぎに，湿合物 $(a \mathrm{~g})$ に塩化第一鉄を所定量 $(b \mathrm{~g})$ 加え， 鉄が全量酸化してへマタイトになるものとし，モル比で (1) 式が満足されたのち，塩化第一鉄扰よび副生へマト タイト中の壏菜の全量と炭酸ストロンチウム $(d \mathrm{~g})<の$ 間でつぎの式が成立するよう炭酸ストロンチウムを追加 添加する。これを実験】という。

$$
\begin{aligned}
& \mathrm{Cl}\left(\mathrm{FeCl}_{2} \cdot 3.8 \mathrm{H}_{2} \mathrm{O}\right. \text { 所定量 } \\
& \text { bgに含まれる Cl) のモル数 }=2.00 \\
& \mathrm{Sr}\left(\mathrm{SrCO}_{3}\right. \text { の添加量 } \\
& \text { dg に含まれる Sr) のモル数 }
\end{aligned}
$$

実験 I とII この原料調製は両者まったく同一に進めた。 混合物に塩化第一鉄と炭酸ストロンチウムの所定量を加 
え，擂䟺機にて10分間筧拌混合したものを用いた。

II -4 仮焼成上本焼成

仮焼成牥 $500^{\circ} \mathrm{C} / \mathrm{hr}$ の速度で昇温し， $1000^{\circ} \mathrm{C}, 30$ 分間筀 気中で行い，冷却後，ステアリン酸を $0.1 \mathrm{wt} \%$ 添加した のち擂溃機で30分間闃拌粉砕を行った。乙れらの仮燒品 を成形在力 0.3 まな $0.4 \mathrm{t} / \mathrm{cm}^{2}$ で断面積 $1 \mathrm{~cm}^{2}$, 高さ約 $10 \mathrm{~mm}$ の圧粉体を作成した。本焼成は磁気特性が良好 となる $1250^{\circ} \mathrm{C} ， 2$ 分間の条件で行った.

\section{II -5 磁気特性の测定}

磁気特性の測定は東英工業(株)製 Cioff 式 TRF-IVA 型自記磁束計を用いた。

\section{III 実験結果亡考察}

Fig. 2,3 亿得られたフェライトの燒結密度および直径 収縮率に与えるへマタイト原料化含まれる塩索の影響に ついて示した. 仮煃品の压粉密度に対する脱塩素の影響 はまったく認められないにすか加うず，いずれのへマ タイトにおいてむ脱塩素処理するととにより 5〜10\%の 焼結密度の向上がみられ，同時代直径収縮率も 8 20\% 大きくなっている，脱塩素の操作として $500 \mathrm{~g}$ のへタタ イトに対して水 11 を加え，1回水洗を行っただけで，へ マタイトの物理的性状である粒径や比表面䆅が大きく変 化したとは考えられないので，塩菜の除去により焼結が 進行しやすくなったためと推定される。

Fig. 4 亿磁気特性に及ぼすへマタイトの種類および脱

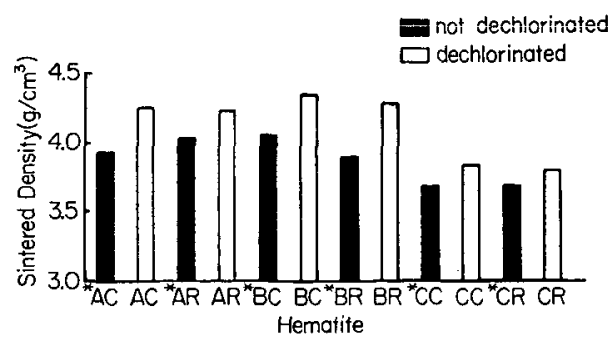

Fig. 2 Effect of dechlorination on the sintered density.

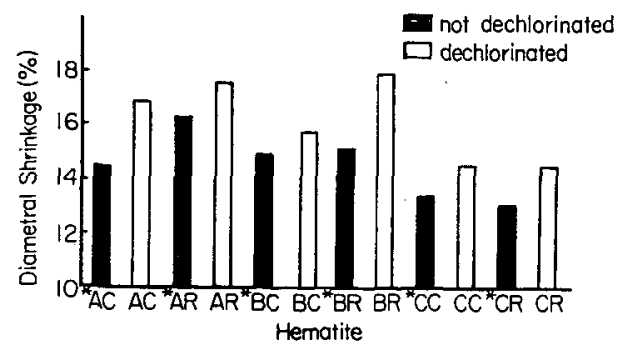

Fig. 3 Effect of dechlorination on the diametral shinkage.
塩素の影響を示す，A 系および B 系のへマタイトから のフェライトの残留磁束密度の值は脱塩素化より約 1.8 $\mathrm{kG}$ 加ら約 $2.0 \mathrm{kG}$ 一之約 $10 \%$ 増大する. しかし，逆化抗 磁力の 值は 3.6 4.0 kOe 加 3.2 3.4 kOe へ之 10 15 \%減少する．これは脱塩素によりすでに推定したように 焼結が促進される現象を偳付けているものと考元られる。 また，最大エネルギー積の值は約 $0.8 \mathrm{MGOe}$ 上脱塩絜に よりほぼ10\%大きな值が得られることが明らかになった。 C系のへマタイトからのフェライトの残留磁束密度の值 は脱塩素によって7〜8\%大きくなるが抗磁力の值は1〜 2\%低下するだけであった。しかし，最大エネルギー皘 の值は A 系および B系のへマタイトと同様10\%ほど增 大している. A 系および B 系へマタイトを原料とした 場合之，C系へマタイトを原料とした場合とで，脱境素 による磁気特性変化はこれらのへマタイトの塩素含有量

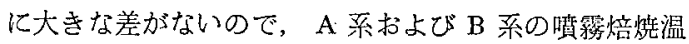
度がそれぞれ $560^{\circ} \mathrm{C} 、 540^{\circ} \mathrm{C}$ 上低く， $\mathrm{C}$ 系では $600^{\circ} \mathrm{C}$ と やや高いため，へマタイト焙焼の熱履歴の差によるもの と考えられる.

次に，へマタイトに塩素を塩化第一鉃の形で添加して 行き，そのとき得られるフェライト中の塩素の形態と分 布について検討した．同㭙に程素を微量添加化合物とし て刺用する方法について実験を進めた。

Fig. 5 (a)，(b) 飞実験 I，几で得られたフェライトの磁 気特性を示す。残留磁束密度および抗磁力上, へマタイ トまたはフェライトに含有する塩素量との関係には，実

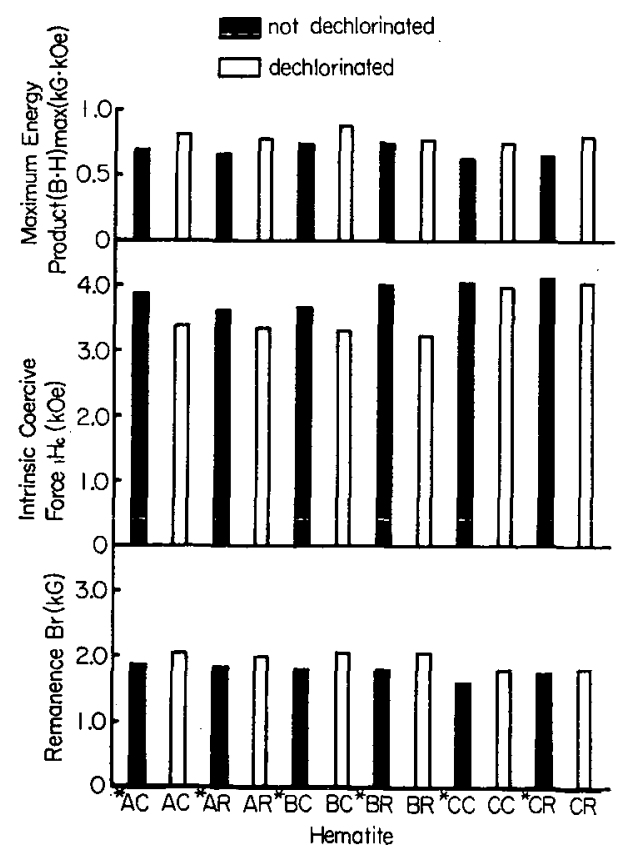

Fig. 4 Effect of dechlorination on the magnetic properties. 
験 IIではへマタイト中の塩甞量が0.1〜5.0\%の範囲で残 留磁束密度の值は最大 $2.46 \mathrm{kG}$ となり，またへマタイト 中の塩素量が0.2\%以上で抗磁力の值は $3.91 \mathrm{kOe}$ となっ た。てれらの值はいずれ実験Ｉのフェライトで得られ た值より杂大きい，最大エネルギー積についても同様に， ヘマタイト中の塩素量が $0.2 \sim 5.0 \%$ 範囲で実験 【 フェライトの值は $1.19 \mathrm{MGOe}$ となり，実験 Iで得られ たものよりあ20〜25\%大きい值を示す.

これらの図で横軸にへマタイトおよびフェライトに含 有する塩素量をそれぞれ示したが，仮崝成にひきつづき 本焼成の過程でフェライトに残存する塩素量はへマタイ

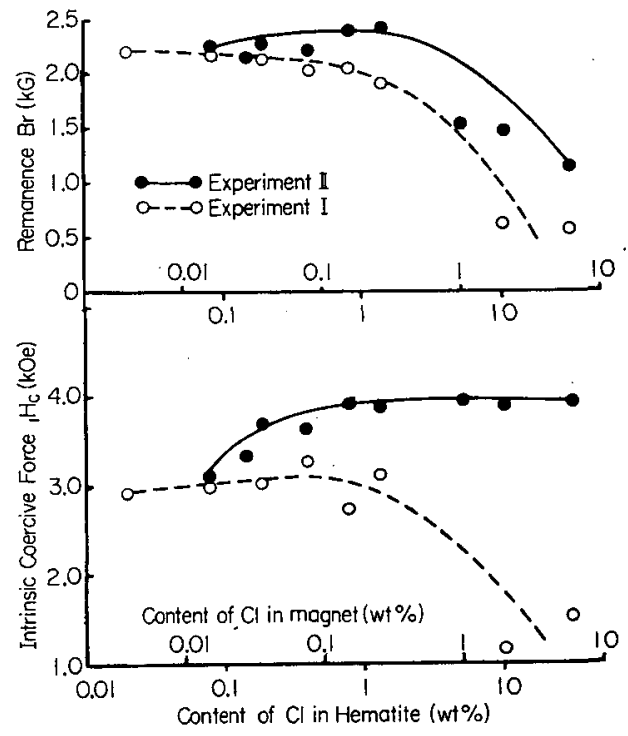

Fig. 5 (a) Effect of chlorine on remanence and intrinsic coercive force.

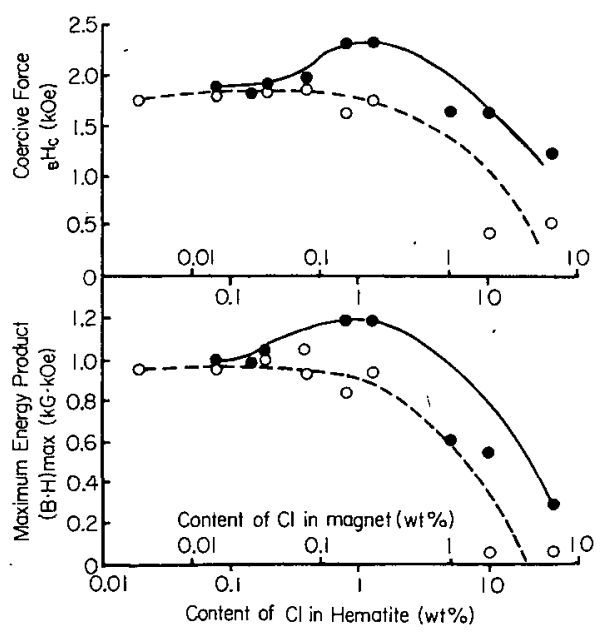

Fig. 5 (b) Effect of chlorine on coercive force and maximum energy product.
トに含有していた最初の重量のほほ20\%になることを示 している.

しかし，実験Пでは実験 I より $d \mathrm{~g}$ だけ炭酸ストロン チゥムを多量に添加混合している加ら，契験 I で認めら れた磁気特性の向上は塩素の効果ではなく、フェライト $\left(\mathrm{SrO} \cdot m \mathrm{Fe}_{2} \mathrm{O}_{3}\right)$ の $m$ の值が 6.00 以下になるた芳え られた。

そこで，塩化第一鉄を添加せずに Fig. 1 の粒度分布 をもつへマタイトと炭酸ストロンチウム老用い，mの值 之残留磁束密度，抗磁力占よび最大エネルギー積との関 係を求めた。結果を Fig. 6 亿示す，図加ら明らかなよ うに $m=5.5$ で残留磁束密度，抗磁力および最大エネル ギー積は最大值を示す。これらの值はへマタイトに塩素 を 0.2〜 5.0 wt \% 添加した実験】の磁気特性よりいずれ あ小さい値となっている. また，Fig. 5 (a)，(b) から残 留磁束密度，抗磁力，最大エネルギー皘などが最大とな るへマタイト中の塩素量は約 $1 \mathrm{wt} \%$ であり，実験 Пの 場合，添加したストロンチウムが塩素と化学反㐫せずに 共存するとして $m$ の值を求めると $m=4.7$ となり, 磁気 特性が最良であるときの $m=5.5$ とは大きな差が認めら れる、そこで実験凹の良好な磁気特性は塩素とこれに対 応する量だけ追加添加した酸化ストロンチウムとの相乘 作用によるものと考えられる。

Table 2 亿実験 I，Пのフェライトの压粉密度，焼結 密度括よび直径收縮率を示す，磁気特性が向上する塩素 量, すなわちへマタイトで $0.2 \sim 5.0 \mathrm{wt} \%$ 範囲内では 実験 II の焼結密度は 4.68 4.76 g/ $\mathrm{cm}^{3}$ であり，塩素量 の少ないフェライトに比必ずしあ大きくなっているわ

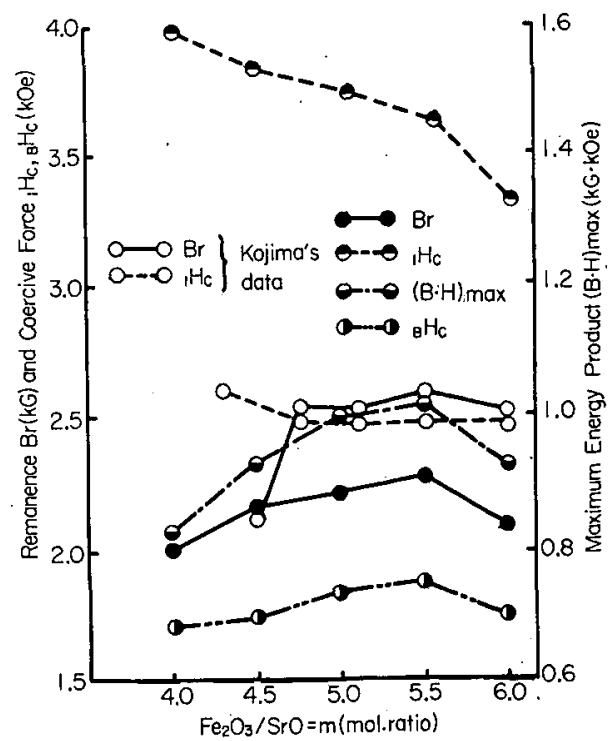

Fig. 6 Relation between magnetic properties and molar ratio. 
Table 2. Effect of chlorine on green density, sintered density and diametral shrinkage.

\begin{tabular}{|c|c|c|c|c|c|c|}
\hline \multirow{2}{*}{$\begin{array}{l}\text { Content of } \mathrm{Cl} \\
\text { in hematite } \\
\text { (wt } \% \text { ) }\end{array}$} & \multicolumn{3}{|c|}{ Experiment I } & \multicolumn{3}{|c|}{ Experiment II } \\
\hline & $\begin{array}{l}\text { Green } \\
\text { density } \\
\quad\left(\mathrm{g} / \mathrm{cm}^{3}\right)\end{array}$ & $\begin{array}{l}\text { Sintered } \\
\text { density } \\
\left(\mathrm{g} / \mathrm{cm}^{3}\right)\end{array}$ & $\begin{array}{c}\text { Diametral } \\
\text { shrinkage } \\
\text { (\%) }\end{array}$ & $\begin{array}{l}\text { Green } \\
\text { density } \\
\left(\mathrm{g} / \mathrm{cm}^{3}\right)\end{array}$ & $\begin{array}{c}\begin{array}{l}\text { Sintered } \\
\text { density }\end{array} \\
\left(\mathrm{g} / \mathrm{cm}^{3}\right)\end{array}$ & $\begin{array}{c}\text { Diametral } \\
\text { shrinkage } \\
\text { (क) }\end{array}$ \\
\hline 0.02 & 2.31 & 4.70 & 21.4 & - & - & - \\
\hline 0.08 & 2.33 & 4.73 & 20.9 & 2.32 & 4.76 & 21.4 \\
\hline 0.15 & - & - & - & 2.37 & 4.71 & 20.6 \\
\hline 0.19 & 2.26 & 4.72 & 21.6 & 2.30 & 4.70 & 19.8 \\
\hline 0.40 & 2.28 & 4.71 & 20.3 & 2.41 & 4.68 & 19.7 \\
\hline 0.80 & 2.27 & 4.37 & 19.0 & 2.36 & 4.71 & 20.3 \\
\hline 1.19 & 2.29 & 3.53 & 12.6 & 2.33 & 4.69 & 20.6 \\
\hline 5.0 & - & - & - & 2.30 & 3.28 & 12.2 \\
\hline 10.0 & 3.11 & 3.27 & 4.4 & 2.38 & 3.55 & 13.7 \\
\hline 30.0 & 3.11 & 3.44 & 4.3 & 2.27 & 3.19 & 13.4 \\
\hline
\end{tabular}

けではない。しかあ，ヘマタイト中の塩素量が 0.8 wt \% 以上になると, 実験 I での燒結密度は実験にに比べ低く なる傾向にある. ヘマタイト中の塩素量が $10 \mathrm{wt} \%$ 以上 になると実験 I, II の両者の焼結密度はともに低下す る.乙れは塩化ストロンチウムの密度が $3.05 \mathrm{~g} / \mathrm{cm}^{3}$ 14) とストロンチウムフェライトの理論密度 $5.1 \mathrm{~g} / \mathrm{cm}^{3}$ 15) に 比べ低く、フェライト結晶粒界, 空隙などをうめてなお 加多量に存在するようになるためと考えられる.

Photo. 1 (a), (b), (c) および (d) に実験 I および Пで 製造した塩素を含有するフェライトのX線回折チャート を示す．塩素が $0.02 \mathrm{wt} \%$ と少ない (a) では塩化ストロ ンチウム $\left(\mathrm{SrCl}_{2}\right)$ の存在は確認できなかったが, 塩素の 添加量を順次 $0.8 \mathrm{wt} \%, 1.19 \mathrm{wt} \%$ と增して行く之 (b),

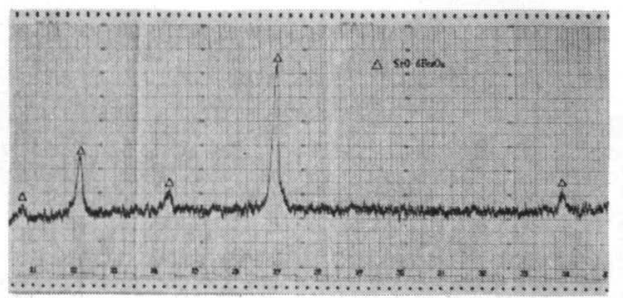

(a) Experiment I: Content of $\mathrm{Cl}$ in hematite. $0.02 \mathrm{wt} \%$

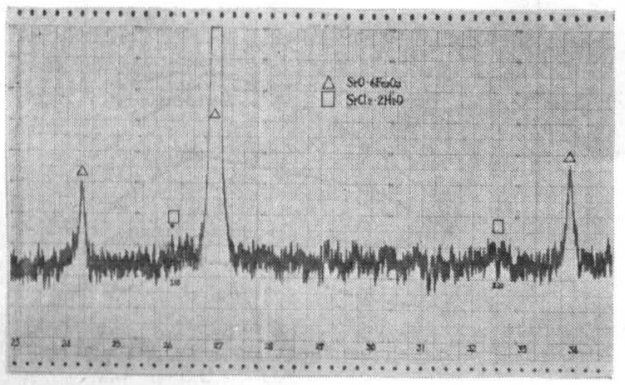

(b) Experiment II: Content of $\mathrm{Cl}$ in hematite. $0.8 \mathrm{wt} \%$ (c) および (d) に認められるように塩化ストロンチウム 2 水塩または 6 水塩が同定されるようになる. しかし, 塩素源として添加した塩化第一鉄の回折ピークは認めら れなかった. とこで塩化ストロンチウムに結晶水が認め られたのは, 本焼成後 X線回折測定までの間に空気中の 水分を吸着することによるあのと考えられた．しかし， フェライト磁石を 6 ケ月以上放置しておいてあ潮解, 起 潤, 寸法変化などの異状は認められなかった。

Photo. 2 に実験 I および【で得たフェライトの顕微 鏡写真を示す． 実験 II の方法で製造したフェライトの 結晶粒子は実験 I のあのよりやや小さくなっている傾向 が認められる，塩素の多い場合では粒界が不明瞭にな る. これは塩化ストロンチウムが焼成時に液相（融点

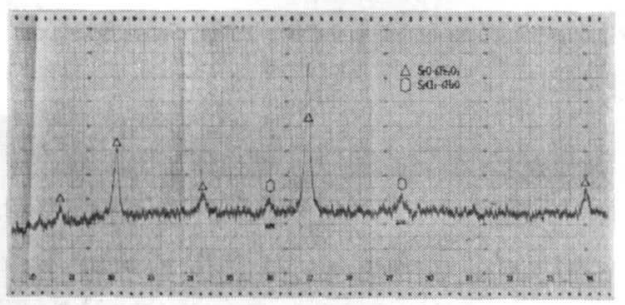

(c) Experiment I: Content of $\mathrm{Cl}$ in hematite. $1.19 \mathrm{wt} \%$

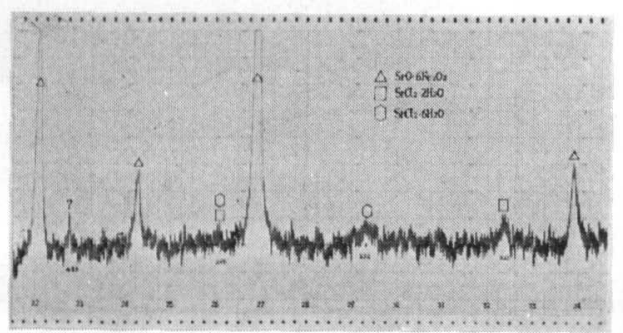

(d) Experiment II: Content of $\mathrm{Cl}$ in hematite. $1.19 \mathrm{wt} \% 6$ Calciration : $1000^{\circ} \mathrm{C} \times 30 \mathrm{~min} \quad$ Sintering: $1250^{\circ} \mathrm{C} \times 2 \mathrm{~min}$

Photo. 1 X-ray diffraction patterns of strontium ferrites containing chlorine. 


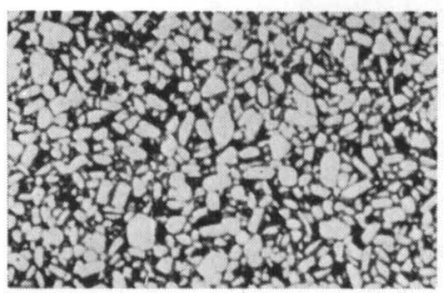

(a) Content of $\mathrm{Cl}$ in hematite: $0.02 \mathrm{wt} \%$
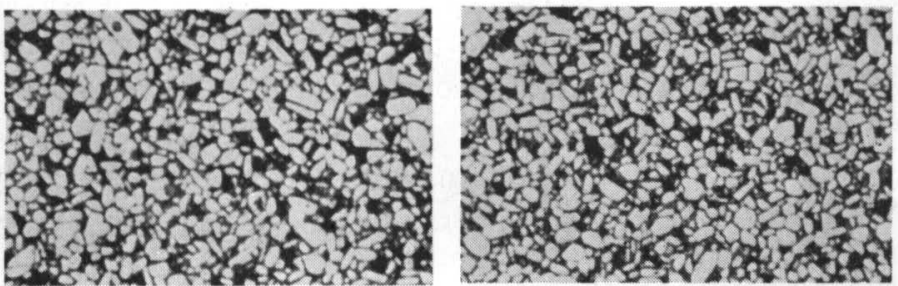

(b) Content of $\mathrm{Cl}$ in hematite: $0.08 \mathrm{wt} \%$
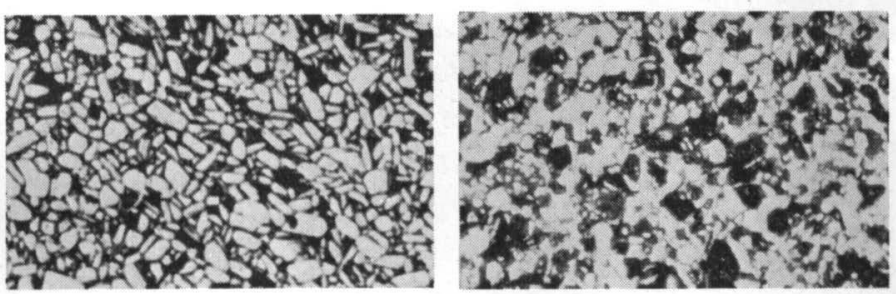

(c) Content of $\mathrm{Cl}$ in hematite: $0.8 \mathrm{wt} \%$
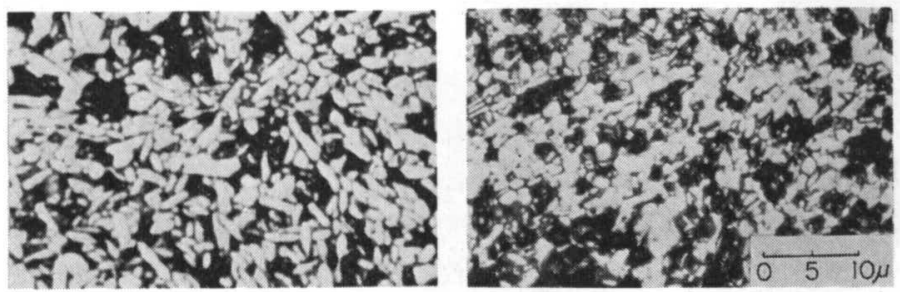

(d) Content of $\mathrm{Cl}$ in hematite: $1.19 \mathrm{wt} \%$
Experiment I.
Experiment II.

Photo. 2 Optical micrograph of strontium ferrites containing chlorine. (Echant: $6 \% \mathrm{HF}$ )
非常に高いので，他の金属塩化物よりフ ェライト中の残存率が大きいととは明ら かである.フェライト中に生成した塩化 ストロンチウムは, $1250^{\circ} \mathrm{C}$ の本焼成で はすでに溶融し，フェライト結晶粒界に はいり込み液相を介してのフェライト化 を促進させる. しかし, フェライト結晶 の粗大化を防ぐ相乗作用によって, 磁気 特性が改善されるあのと考えられる. し たがって, 前者により残留磁束密度の向 上が，後者によって抗磁力の向上が得ら れるあのと考えられる.

フェライト中の残存塩素は化学分析の 結果, 最初のへマタイトに含まれる塩素 量の約 $20 \%$ (フェライト中の鉄を酸化第 二鉄としててれに対する比率では約 25 \%)になる，乙の塩素量がしだいに低く なるに従って, 残留磁束密度, 抗磁力お よび最大エネルギー積の值のいずれも低 下し, ヘマタイトの塩素量が $0.1 \mathrm{wt}$ \% 6 下では炭酸ストロンチウムの追加添加に よる磁気特性改善の効果は認められなく なる. 少量の塩素を含むへマタイトから のフェライトの残留磁束密度の向上が得 られないのは, フェライトの液相焼結に 寄与する塩化ストロンチウムの絶対量が 不足するためと考えられる.すでに実験 で明らかにされたように, 少量の塩素を 含むへマタトを用いる場合にはむしろ 脱塩素の勃果のほうが顕著に認められる. このときは，抗磁力の值は脱塩素により 低下する.

実験 I では追加添加する塩素および鉄 $\left.872^{\circ} \mathrm{C}\right)^{16)}$ となり, 冷却時に粒界に晶析して, 6 wt $\%$ フ ッ酸でエッチングする際に流出したためと考えられる.

Photo. 3 にフェライトに含まれる塩素が 0.08 wt \% 場合のX線マイクロアナライザーによる反射電子像と特 性X線像を, Photo. 4 にフェライト粒界と直角方向の鉄 ストロンチウムおよび塩素に関するラインアナリシスの 結果を示した. これらの結果から, 塩素とストロンチウ ムが粒界に偏析していることが確認された.

フェライトの磁気特性向上の理由はつぎのように考え られる. まず, 塩素と酸化ストロンチウムまたは炭酸ス トロンチウムとが仮焼成と本焼成時に何らかの化学反応 を起とし，X線回折で認められたように塩化ストロンチ ウムに变化する．塩化ストロンチウムの蒸気圧が 760 $\mathrm{mmHg}$ となる温度は $1250^{\circ} \mathrm{C}$ で他の金属塩化物に比へ
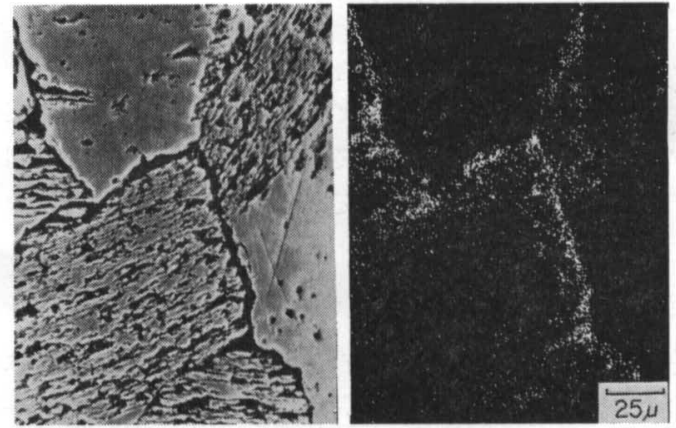

Backscattered electron image.

$\mathrm{Cl}$

Photo. 3 Backscattered electron image and distribution of chlorine by electron microprobe analysis of $\mathrm{SrO} \cdot 6 \mathrm{Fe}_{2} \mathrm{O}_{3}$ containing 0.08 wt $\%$ chlorine. 


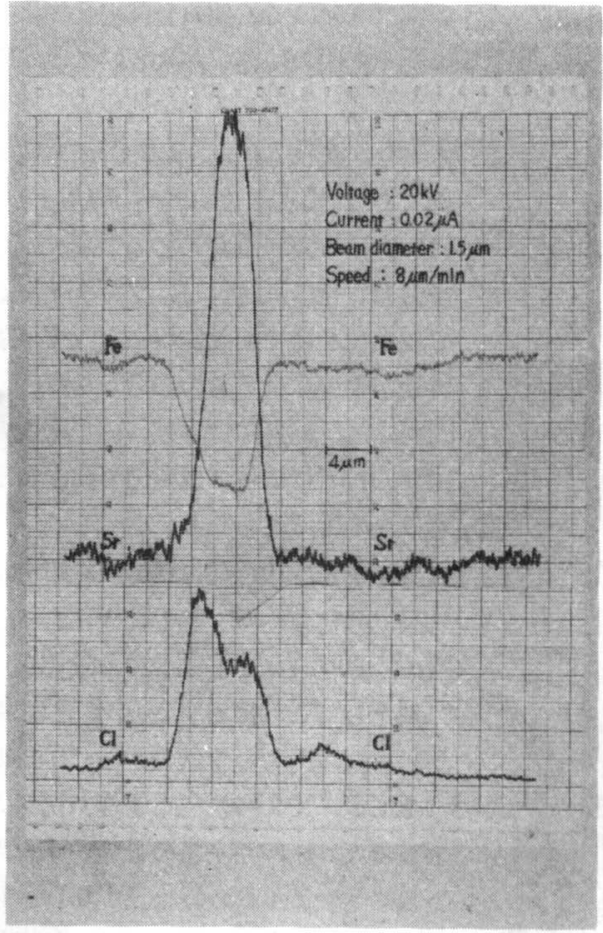

Photo. 4 Line analysis of grain boundary of SrO. $6 \mathrm{Fe}_{2} \mathrm{O}_{3}$ containing $0.08 \mathrm{wt} \%$ chlorine by electron microprobe analyzer.

に対し，ストロンチウムの補償添加を行わないため, フ ェライトの $m$ の值が 6.00 より大きくなって磁気特性の 低下がおこるものと考えられる，しかし，実験 【に㧍 いてはフェライトの焼結密度が $1.18 \mathrm{wt} \%$ までの塩素の 添加では, ほぼ一定の值に保たれるにもかかわらず残留 磁束密度の向上が得られた. との理由はつぎのように考 えられる.すなわち，第 1 に，前述したように塩化ス卜 ロンチウムの液相による焼結の促進作用, 第 2 に, 仮焼 品を粉砕したときに生ずる微粉が液相焼結により他のそ れらより大きいフェライト粒子に併合され，適度の大き さの粒子に整粒される作用, 第 3 亿, 仮焼品の圧粉体が 液相焼結される過程で圧粉体の加圧軸方向にフェライト 粒子の $c$ 軸方向が整列されやすくなる作用, などがある ためではないかと推定される．とれらの問題については 今後検討を進める予定である.

\section{IV ま と め}

（1）副生へマタイトに含まれる微量塩素分の等方性ス トロンチウムフェライトの磁気特性に与える影響はつぎ のようにまとめられる.

(i) ヘマタイトに含まれる $0.1 \sim 0.3 \mathrm{wt} \%$ の塩素分を, 2 倍重量の水で 1 回水洗するととにより約 $50 \%$ 脱塩素す るととができる. (ii) ヘマタイトの脱塩素によって，フェライト仮焼 品の圧粉密度の值は変化しないにあかかわらず, それら の焼結密度の值は 5 10\%大きな值が得られる.

(iii) 脱塩素したへマタイトを用いて得られるフェラ イトの抗磁力の值は10 15\%減少するが, 残留磁束密度, 最大エネルギー積の值はそれぞれ約10\%増大する.

(iv) 以上から, 脱塩素により蛄結が促進されるあの と考えられる.

（2）へマタイトに塩素を塩化第一鉄の形で添加して得 られたフェライトの磁気特性に及ぼす影響はつぎのよう にまとめられる.

(i) $2 \mathrm{Fe} / \mathrm{Sr}=6.00$ のフェライトで磁気特性が著しく低 下しないへマタイト中の塩素分の許容量は $0.5 \mathrm{wt} \%$ まで である.

(ii) 前記モル此が満足されたのち $2 \mathrm{Cl} / \mathrm{Sr}=1.00$ の組 成までストロンチウムの補償添加をしたあのは, 前記モ ル比のまま作成したフェライトに比べ良好な磁気特性が 得られる. このとき, 最良の磁気特性は塩素分 $0.8 \sim 1.0$ wt \%の範囲で得られる.

(iii) フェライトに含まれる塩素分は塩化ストロンチ ウムとして存在し, フェライトの結晶粒界または空孔に 偏析しているととが明らかになった.

(iv) 塩素をストロンチウムで補償したフェライトの 抗磁力の向上は塩化ストロンチウムがそのフェライトの 結晶粒界に存在するためと考えられる. また, 焼結密度 がほぽ定に保たれるにもかかわらず残留磁束密度が著 しく向上する理由は，塩化ストロンチウムがストロンチ ウムフェライト焼成過程において液相となり, 焼結を促 進するが粒子の整粒之粗大化防止の機能をむつためと考 えられる.さらに, 塩化ストロンチウムの液相の出現に より，たとえば圧縮軸方向に結晶方位が整列されること により残留磁束密度と最大エネルギー積の著しい向上が 得られるあのと推定される. この点について今後研究を 進める予定である.

\section{参考 文 献}

1）小林, 暮原, 小田：粉体护よび粉末治金 10 (1968), 215.

2）岸高，谷原，伊藤，宮川，嵯峨：川鉄技報 1 (1969), 53.

3) H. Dembeck: Bänder Bleche Rohre 5 (1964), 9.

4）旦本無機工業薬品協会：“昭和47年度 年間酸化第二鉄生 産出荷実績表” (Mar. 1973).

5) M. J. Ruthner, H. G. Richter, I. L. Steiner: "FERRITES", Proceeding of the International Conference, Jul. 1970, Japan; University of Tokyo Press, (1971), 75.

6）山元，エレクトロニク・セラミックス：〔9] (1972), 63.

7) 高田, 木山, 坂東：日本特許公告, 昭46-11704 11707.

8）岡村, 小島, 渡辺：日本金属学会誌, 19 (1955), 464.

9）小島：同誌, 19 (1955), 632.

10）多田：日本特許公開，昭48-9297.

11）武井：“フェライトの理論と応用 II” 丸善 ( $(1960), 251$. 
12) A. Cochardt: J. Appl. Phys., 34 (1963), 1273; 37 (1966), 1112; 38 (1967), 1904.

13）コッホアルト：日本特許公告, 昭39-12383, 昭40-5979; 昭40-25303.

14) J. W. Mellor: "A comprehensive treatise on in- organic and theoretical chemisty", Longmans (England) III, (1960), 700.

15）原田：金属, 42 (1972), 95.

16）化学工業協会編：“物性常数表 3 集”, 丸善, (1964)，98.

17）日本化学会編：“化学便覧” 丸善 (1952) 13.

\section{テキスト頒分のご案内}

下記の俩演概要集およびテキストを購入ご希望の方は, 現金書留にて事務局へお申し込み下さい，なお，在庫の 少ないあのあありますので，品切れになりました節は徳 しからずご容数下さい。

\section{第 6 回粉末冶金入門講座テキスト (49年 6 月)}

\section{B 5 判 180頁 頒価 2,400円（开共）}

目次

1. 粉末治金工業の情報分析

一粉末治金工業近代化への道亡 新時代への対応性一-

（日本粉末治金工業会）中川真澄

2. 焼結機械部品の経済性 （住電）川北宇夫

3. 粉末治金用金属粉の性質とその測定法

（金材研）田村皖司

4. 金属粉の成形法

5. 燒結とは

6. 超硬合金について

7. 焼結銭造とは

8. 焼結機械構造部品について (三菱金属) 的場敏夫

9. 焼結含油軸受について

10. 新しい狫結材料について

渡辺化尚

\section{分科会合同技術討論会講演概要集}

(49年 2 月）

\section{B 5 判 41頁 頒価 1,200円（共）}

テーマ: 複合材料としての焼結材料

目次

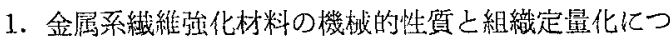
いて

（早大）中田 栄一

2. 結晶化ガラスならびに多結晶体の強度 （三重大）作花 斎夫

3. 無機繊維上その複合材料（名大）斉藤 肇

4. 複合材料上しての超硬合金 （東大）鈴木 辈

5. フェライトにおける複合材料 (理研) 杉本 光男

6. 酸化亚鉛焼結体の微細椿造と非オーム性

（松下電器）松岡 道雄

第 3 回焼結金属材料の摩擦摩耗に関する 講演会講演概要集

（48年11月）
目次

1. 杽摖歑耗の概論

2. 烧結合金材料の摩擦摩耗

（理研）曾田 範宗

3. 摩擦摩耗の試験方法

（早大）葉山 房夫

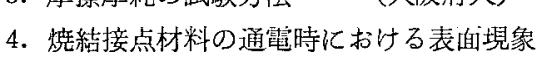

（住電） 權山 資章

5. 摩耗データーの解析方法

（東大）佐田登志夫

6. Al 系狫結合金の摩擦摩耗一粘着増強用しゅう動 子一 （鉄道技研） 熊谷 正博

7. 合成制輸子と車輸の摩耗

（近鉄）中井実, 斎藤 禎夫

8. 固体润滑の概論（オイレス工業）多田博

\section{新しい焼結材料に関するセミナーテキスト}

(48年 9 月)

\section{B 5 判 55頁 須価 1,000円（干共）}

目次

1. 粉沭治金工業の将来之課題

（東京焼結金属）内藤 逸策

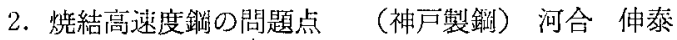

3. 焼結耐熱材料の問題点之将来（東芝）鈴雄

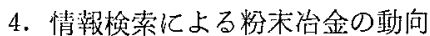

5. $\mathrm{Al}$ 焼結機械構成部品

（豐田中研）木村 尚

6. Al-Cu 系焼結含油軸受

(住電)，本吉 健也

（日本科学冶金）松川 清喬

7. Ti 燒結部品の将来 (三菱金属) 西野 良天

8. 粉末压延法の現状之将来 （金材研）田村 皖司

9. 粉末玨延法による $\mathrm{Ti}$ 薄板の製造

（金材研） 村松 祐治

\section{春・秋講演大会講演概要集}

B 5 判 頒価各 2,000円（干共）

昭和 45 年度春季大会 (東京)

109 頁 $\stackrel{\text { 講演数 }}{(36 \text { 件 })}$

昭和 45 年度秋季大会 (京都)

121頁 (60件)

昭和 46 年度春季大会 (東京)

170貢 (58件)

昭和 46 年度秋季大会 (名古屋)

185頁 (63件)

昭和 48 年度春季大会（東京）

183頁 (62件)

昭和 48 年度秋季大会（金沢）

232頁 （80件）

昭和 49 年度春季大会 (京都)

\section{B 5 判 41頁 頒価 1,000円（共）}

